\title{
A cross-sectional study of secondhand smoke exposure and respiratory symptoms in non- current smokers in the U.S. trucking industry: SHS exposure and respiratory symptoms
}

\author{
Francine Laden ${ }^{1,2,3^{*}}$, Yueh-Hsiu Chiu ${ }^{1}$, Eric Garshick ${ }^{3,4}$, S Katharine Hammond ${ }^{5}$ and Jaime E Hart ${ }^{1,3}$
}

\begin{abstract}
Background: Previous studies have suggested associations of adult exposures to secondhand smoke (SHS) with respiratory symptoms, but no study has focused on blue-collar industrial environments. We assessed the association between SHS and respiratory symptoms in 1,562 non-current smoking U.S. trucking industry workers.

Methods: Information on SHS exposure and respiratory health was obtained by questionnaire. Multiple logistic regression analyses were used to assess the associations of recent and lifetime exposures to SHS with chronic phlegm, chronic cough, and any wheeze, defined by American Thoracic Society criteria.

Results: In analyses adjusted for age, gender, race, childhood SHS exposure, former smoking, pack-years of smoking and years since quitting, body mass index, job title, region of the country, and urban residence, recent exposures to SHS were associated with all three respiratory symptoms (odds ratio $(\mathrm{OR})=1.46$; $95 \%$ confidence interval $(\mathrm{Cl})=1.00$ 2.13) for chronic cough, 1.55 ( $95 \% \mathrm{Cl}=1.08-2.21)$ for chronic phlegm, and 1.76 ( $95 \% \mathrm{Cl}=1.41-2.21)$ for any wheeze). Workplace exposure was the most important recent exposure. Childhood exposure to SHS was also associated with all three symptoms, but only statistically significantly for chronic phlegm $(\mathrm{OR}=1.84 ; 95 \% \mathrm{Cl}=1.24-2.75)$. Additional years of living with a smoker were associated with an increased risk, but there was no evidence of a dose-response, except for chronic phlegm.
\end{abstract}

Conclusions: In this group of trucking industry workers, childhood and recent exposures to SHS were related to respiratory symptoms.

Keywords: Occupational health, Secondhand smoke, Respiratory symptoms

\section{Background}

Secondhand smoke (SHS) is a complex mixture of chemicals generated by the burning of tobacco and the smoke exhaled by smokers [1]. Previous studies have suggested that adult exposure to SHS may be associated with adverse respiratory effects including acute and chronic respiratory symptoms, chronic rhinosinusitis, and asthma [1-10]; furthermore, the burden of respiratory symptoms on health related quality of life may

\footnotetext{
* Correspondence: francine.laden@channing.harvard.edu

'Department of Environmental Health, Harvard School of Public Health, Boston, MA, USA

2Department of Epidemiology, Harvard School of Public Health, Boston, MA, USA

Full list of author information is available at the end of the article
}

be even stronger than that of lung function [11]. Epidemiologic studies of SHS exposure and respiratory symptoms have mainly considered office environments or service workers (in bars, restaurants, and casinos), but no study that we know of has focused on blue-collar industrial environments. Smoking prevalence in adults has been declining in the U.S. [12-14], but among the major blue-collar occupations it remains higher than that of many other occupational groups [15-20], suggesting that this is a population that still has high potential for SHS exposure [21]. Our previous work also found that despite state and local movements toward smoke-free laws, U.S. trucking industry workers were still exposed to workplace SHS as recently as 2005 [22]. 
In this study, we examined the association between SHS exposure and self-reported chronic respiratory symptoms, including cough, phlegm and wheeze, in a population of non-smoking employees in the U.S. unionized trucking industry.

\section{Methods \\ Study subjects}

In 2004 we mailed a health questionnaire to 3,689 members of the International Brotherhood of Teamsters, working or recently retired (within 7 years) from three large U.S. trucking companies. These individuals were all respondents to a previous questionnaire focused on active smoking habits [23]. We were unable to relocate 104 individuals and received responses from 2,294. The participants represented the major job categories in the trucking industry: long-haul driver (driving between cities), pick-up/delivery (P\&D) driver (local driving within cities), dock worker (moving freight within the terminal), combination worker (workers who work both on the dock and drive P\&D trucks), mechanic (repairing tractors and trailers), hostler (moving trucks in the terminal yard), and clerk (office worker). The study protocol was approved by the Brigham and Women's Hospital, the Harvard School of Public Health and VA Boston Institutional Review Boards and consent was inferred from return of the completed questionnaires.

\section{Respiratory symptoms and illness}

Prevalence of chronic respiratory symptoms was identified based on self-reports using questions from the American Thoracic Society DLD-78 questionnaire that includes questions on timing and severity of the symptoms [24]. "Chronic cough" was defined as cough on most days for 3 consecutive months or more during the year. "Chronic phlegm" was defined as phlegm on most days for 3 consecutive months or more during the year. "Any wheeze" was any report of wheezing with a cold or occasionally apart from colds or on most days or nights. Information on other respiratory illnesses, including hay fever, chronic bronchitis, emphysema, chronic rhinitis, chronic obstructive pulmonary disease (COPD), and asthma, was also obtained. In sensitivity analyses, we excluded all participants with existing doctor diagnosed chronic respiratory disease.

\section{Secondhand smoke exposure}

We examined several metrics of SHS exposure. First, we used a previously validated question on exposure to SHS in the past 7 days from all sources. Workers were classified as "exposed" if they reported "yes" to "In the past 7 days, have you been exposed to someone else's tobacco smoke?". We also obtained information on recent home and recreational SHS exposures during an average week, as well as workplace exposure in the past 2 work days, and used this information to identify the likely sources of current SHS exposure. Recent home exposure was identified by the question "Has anyone (not including you) smoked tobacco in your home in the past 7 days?" (yes/no). Recreational and workplace exposures were identified based on time spent at places where people were smoking (restaurants, bars, clubs, other people's homes, sports arena, concerts, etc.) in an average week, and amount of time spent in areas at work where smoking was allowed in the past 2 work days. Individuals were considered non-exposed if they did not spend time at smoking allowed areas or if they spent time there but reported no one was smoking.

We also examined two measures of chronic SHS exposure. Childhood SHS exposure was defined by whether the individual had ever lived with at least one smoker during their childhood (yes/no). Long-term exposure to SHS at home was identified by lifetime total years of residency with at least one smoker, and was categorized into four groups $(<10,10-19,20-29$, and $\geq 30$ years $)$.

\section{Statistical analysis}

We used multiple logistic regression and estimated the odds ratio (OR) and 95\% confidence intervals (95\% CI) to evaluate the association between each SHS exposure metric and chronic cough, chronic phlegm, and any wheeze in separate models. We examined recent and long-term exposure to SHS in separate and combined models.

We considered, as potential confounders, variables that were either biologically meaningful or statistically significant in univariate analyses. These factors included childhood SHS exposure (in models of current exposure), previous smoking history (status, pack years smoked, and years since quit for former smokers), age, gender, race (white vs. nonwhite), job title, U.S. Census region (South, West, Midwest, Northeast), urban/nonurban residence, body mass index (BMI; weight divided by height squared, $\mathrm{kg} / \mathrm{m}^{2}$ ), and self-reported medical history. Job title was included to control for differences in occupational exposures to air pollutants [25] and unmeasured lifestyle characteristics, and was categorized into four groups: drivers, terminal workers (dock workers and hostlers), office workers, and retired. Furthermore, we assessed effect modification on the relationship between current, childhood, and lifetime SHS exposure and respiratory symptoms by former smoking, childhood or current SHS exposure (as appropriate), race, obesity $\left(\mathrm{BMI} \geq 30 \mathrm{~kg} / \mathrm{m}^{2}\right)$, and urban residence using stratified analyses and interaction terms. All analyses were performed in the SAS statistical package (version 9.1.3, SAS Institute Inc., Cary, NC). 


\section{Results}

\section{Participant characteristics}

Only never smokers or former smokers who had quit smoking more than 10 years before completing the questionnaire and who completed the question on exposure to SHS in the past 7 days were eligible for analysis $(n=$ 1,562). Participant characteristics, current and childhood SHS exposure, as well as prevalence of respiratory health outcomes are presented in Table 1 . The study population was predominantly Caucasian, had a median age of 54 years and a median BMI of $29.0 \mathrm{~kg} / \mathrm{m}^{2}$. About $63 \%$ of participants reported that they were exposed to SHS in the past 7 days and $70 \%$ were exposed to SHS during their childhood. There were $9.8 \%$ who reported chronic cough, $11.7 \%$ chronic phlegm, $47.8 \%$ any wheeze, and $50.8 \%$ with any symptoms.

\section{SHS exposure and respiratory symptoms}

The results from the multivariable logistic regression models assessing the association of the different exposure metrics with each respiratory symptom are presented in Table 2. Adjusting for childhood SHS exposure and other potential confounders, exposure to SHS in the past 7 days was statistically significantly related to all symptoms. When simultaneously examining current SHS exposure by different locations/sources, workplace exposure and recreational exposures were the most important. Childhood SHS exposure was associated with an elevated risk of all symptoms, but was only statistically significantly associated with an increased risk of chronic phlegm. Lifetime SHS exposure at home was positively associated with all three symptoms.

\section{Effect modification}

In stratified analyses (Table 3) we observed stronger associations of SHS exposure in the last 7 days with chronic cough and phlegm among those without childhood exposure to SHS and with chronic phlegm for those currently living in a non-urban area, although only the interaction term for urban/rural difference for chronic phlegm was statistically significant. On the other hand, we found stronger relationships of childhood SHS exposure with all respiratory symptoms among obese workers and those currently living in urban areas. The interactions were statistically significant between childhood SHS exposure and obesity for any wheeze $(p=$ 0.02). In stratified analyses of the effects of lifetime home SHS exposure (Table 4), there was little evidence of effect modification, except by obesity, with stronger relationships among obese participants. In models restricted to individuals without chronic respiratory disease, results were similar (data not shown).
Table 1 Characteristics and SHS exposure of 1,562 noncurrent smoking workers in the U.S. unionized trucking industry

\begin{tabular}{|c|c|c|}
\hline Continuous variables & \multicolumn{2}{|c|}{ Median (IQR) } \\
\hline Age (years) & \multicolumn{2}{|c|}{$54(48-61)$} \\
\hline $\mathrm{BMI}\left(\mathrm{kg} / \mathrm{m}^{2}\right)$ & \multicolumn{2}{|c|}{$29.0(25.8-31.3)$} \\
\hline Total years lived with smokers (years) & \multicolumn{2}{|c|}{$20(7-30)$} \\
\hline Pack-years of active smoking* & \multicolumn{2}{|c|}{$15(5-30)$} \\
\hline Years since quit smoking* & \multicolumn{2}{|c|}{$22(17-30)$} \\
\hline Categorical Variables & $\mathbf{N}$ & (\%) \\
\hline Male & 1331 & 85.2 \\
\hline Caucasian & 1404 & 89.9 \\
\hline Former smoker & 692 & 44.3 \\
\hline \multicolumn{3}{|l|}{ Job title } \\
\hline Terminal worker & 203 & 13.0 \\
\hline Driver & 791 & 50.6 \\
\hline Office worker & 228 & 14.6 \\
\hline Retired & 308 & 19.7 \\
\hline \multicolumn{3}{|l|}{ Region of Residency } \\
\hline South & 494 & 31.6 \\
\hline West & 278 & 17.8 \\
\hline Midwest & 521 & 33.4 \\
\hline Northeast & 269 & 17.2 \\
\hline Living in urban area & 1034 & 66.2 \\
\hline Exposed to SHS in the past 7 days & 990 & 63.4 \\
\hline \multicolumn{3}{|l|}{ Current SHS exposure } \\
\hline Recent home exposure & 158 & 10.4 \\
\hline Recent workplace exposure & 413 & 30.6 \\
\hline Recent recreational exposure & 1127 & 80.5 \\
\hline Childhood SHS exposure & 1077 & 70.1 \\
\hline \multicolumn{3}{|l|}{ Respiratory symptoms } \\
\hline Chronic cough & 153 & 9.8 \\
\hline Chronic phlegm & 183 & 11.7 \\
\hline Any wheeze & 718 & 47.8 \\
\hline Any symptom & 793 & 50.8 \\
\hline
\end{tabular}

$\mathrm{IQR}=$ interquartile range; $\mathrm{BMI}=$ body mass index.

* Among never smokers and former smokers who quit at least 10 years before completing the questionnaire.

\section{Discussion}

In this population of non-smoking blue-collar trucking industry workers, we observed statistically significant relationships of recent SHS exposure with self-reported respiratory symptoms, including chronic cough, chronic phlegm, and any wheeze. Workplace appeared to be an important source of current exposure to SHS that influenced the workers' respiratory health. In addition, childhood exposure to SHS was statistically significantly 
Table 2 Association between SHS exposure and respiratory symptoms among 1,562 non-smoking workers a

\begin{tabular}{|c|c|c|c|c|c|c|}
\hline \multirow[t]{2}{*}{ SHS exposure } & \multicolumn{2}{|c|}{ Chronic cough } & \multicolumn{2}{|c|}{ Chronic phlegm } & \multicolumn{2}{|c|}{ Any wheeze } \\
\hline & OR & $95 \% \mathrm{Cl}$ & OR & $95 \% \mathrm{Cl}$ & OR & $95 \% \mathrm{Cl}$ \\
\hline \multicolumn{7}{|l|}{ Total recent exposure } \\
\hline Exposed to SHS in past 7 days & 1.46 & $1.00-2.13$ & 1.55 & $1.08-2.21$ & 1.76 & $1.41-2.21$ \\
\hline \multicolumn{7}{|l|}{ Current exposure by location $\mathrm{b}_{\mathrm{b}, \mathrm{c}}$} \\
\hline Recent workplace exposure ${ }^{d}$ & 1.74 & $1.14-2.67$ & 1.75 & $1.16-2.65$ & 1.20 & $0.90-1.60$ \\
\hline Recent home exposure ${ }^{\mathrm{e}}$ & 0.74 & $0.37-1.48$ & 0.76 & $0.41-1.42$ & 0.90 & $0.60-1.35$ \\
\hline Recent recreational exposure ${ }^{f}$ & 0.91 & $0.55-1.50$ & 1.24 & $0.74-2.09$ & 2.03 & $1.45-2.83$ \\
\hline \multicolumn{7}{|l|}{ Childhood exposure } \\
\hline Lived with $\geq 1$ smoker during childhood & 1.21 & $0.81-1.80$ & 1.84 & $1.24-2.75$ & 1.16 & $0.91-1.47$ \\
\hline \multicolumn{7}{|l|}{ Life-time home exposure } \\
\hline Less than 10 years & Ref & - & Ref & - & Ref & - \\
\hline 10-19 years & 1.39 & $0.84-2.31$ & 1.86 & $1.15-3.03$ & 1.21 & $0.90-1.63$ \\
\hline 20-29 years & 1.75 & $1.04-2.94$ & 1.92 & $1.16-3.18$ & 1.17 & $0.85-1.60$ \\
\hline \multirow[t]{2}{*}{ at least 30 years } & 1.35 & $0.79-2.32$ & 1.91 & $1.15-3.17$ & 1.30 & $0.94-1.79$ \\
\hline & \multicolumn{2}{|c|}{$p$ trend $=0.29$} & \multicolumn{2}{|c|}{$p$ trend $=0.02$} & \multicolumn{2}{|c|}{$p$ trend $=0.12$} \\
\hline
\end{tabular}

${ }^{a}$ Logistic regression models adjusted for age, sex, race, job title, former smoking, pack-years, years since quitting, BMl, region of country, and urban residence among never smokers or former smokers who quit at least 10 years before completing the questionnaire.

${ }^{b}$ Additionally adjusted for childhood exposure to SHS.

c Location specific exposures were all modeled simultaneously.

d Exposure at work in the past 2 work days.

e Recent exposure at home in an average week.

${ }^{f}$ Recent exposure outside of home and work in an average week.

Note: trend analyses are estimated using the median value of each category.

associated with chronic phlegm, whereas life-time duration of SHS exposure at home was positively associated with chronic phlegm and any wheeze. We also found evidence of effect modification by obesity and urban residence on the association between childhood SHS exposure and respiratory symptoms.

Our findings are fairly consistent with results from previous studies, although the evidence has been less conclusive in studies of adults than in studies of children. Studies have considered many combinations of SHS exposure experienced in childhood, adulthood, at home, at work, and outside of home or work. In addition, multiple outcome measures have been assessed (e.g. cough, phlegm, wheeze, chest tightness, breathlessness/dyspnea, headache, sinusitis, etc.), either by selfreports or doctor diagnosis. Therefore, it is difficult to make a concise comparison of studies.

Studies evaluating relationships between home SHS exposures (i.e. living with a smoker as an adult) and respiratory symptoms have observed inconsistent results, ranging from no association to an almost four-fold risk of chronic or usual cough [4,9,26-31]. In our study, no associations between home exposure and symptoms were found after controlling for current workplace exposure, but there was a significant association between total duration of life-time home exposure and chronic phlegm. Fewer studies have evaluated the effect of childhood SHS exposure on adult respiratory symptoms [26,32-34]. In a study of never smoking Singaporeans aged 45-74 years, positive associations were observed for childhood exposure with chronic phlegm and cough in adulthood [26]. A multicenter study in India showed positive association between exposure during childhood and both during childhood and adulthood with the prevalence of asthma [34]. A study in Western Norway revealed a significantly positive association between maternal smoking in childhood and wheeze in adulthood, but the results were not statistically significant for phlegm and cough [32]. The association between childhood exposure and adult wheeze was also observed in a multi-area European study, but this association was no longer statistically significant when restricted to never smokers [33]. In our present study of non-current smoking workers, childhood SHS exposure had a significant association with chronic phlegm and a borderline association with wheeze, after adjusting for current SHS exposure.

Analyses of self-reported workplace exposures have revealed more consistent associations with elevated risks of respiratory symptoms $[6,9,35,36]$. In a prospective diary study as part of the SAPALDIA study in never smoking Swiss adults, SHS exposure at work was 
Table 3 Effect modifications on the association between SHS exposure and respiratory symptoms among 1,562 noncurrent smoking workers ${ }^{a}$

\begin{tabular}{|c|c|c|c|c|c|c|c|c|c|c|}
\hline \multirow[t]{2}{*}{ Exposure metric } & \multirow[t]{2}{*}{ Stratification factors } & \multicolumn{3}{|c|}{ Chronic cough } & \multicolumn{3}{|c|}{ Chronic phlegm } & \multicolumn{3}{|c|}{ Any wheeze } \\
\hline & & $\mathrm{n}$ & OR & $95 \% \mathrm{Cl}$ & $\mathrm{n}$ & OR & $95 \% \mathrm{Cl}$ & $\mathrm{n}$ & OR & $95 \% \mathrm{Cl}$ \\
\hline \multirow[t]{12}{*}{ Current Exposure } & Former smoking & & & & & & & & & \\
\hline & No & 870 & 1.62 & $0.97-2.69$ & 870 & 1.48 & $0.92-2.38$ & 840 & 1.78 & $1.32-2.39$ \\
\hline & Yes & 692 & 1.31 & $0.73-2.33$ & 692 & 1.69 & $0.98-2.93$ & 662 & 1.73 & $1.21-2.45$ \\
\hline & Obesity (BMI $\geq 30 \mathrm{~kg} / \mathrm{m}^{2}$ ) & & & & & & & & & \\
\hline & No & 1033 & 1.68 & $1.04-2.73$ & 1033 & 1.27 & $0.81-1.98$ & 995 & 1.72 & $1.31-2.26$ \\
\hline & Yes & 522 & 1.19 & $0.64-2.22$ & 522 & 2.06 & $1.11-3.83$ & 500 & 1.99 & $1.33-2.99$ \\
\hline & Currently in urban area & & & & & & & & & \\
\hline & No & 528 & 2.39 & $1.14-4.99$ & 528 & 2.97 & $1.46-6.01$ & 506 & 2.07 & $1.40-3.05$ \\
\hline & Yes & 1034 & 1.24 & $0.78-1.95$ & 1034 & 1.19 & $0.78-1.83$ & 996 & 1.67 & $1.26-2.22$ \\
\hline & Childhood SHS exposure & & & & & & & & & \\
\hline & No & 459 & 2.31 & $1.06-5.02$ & 459 & 2.42 & $1.06-5.53$ & 437 & 1.41 & $0.94-2.13$ \\
\hline & Yes & 1077 & 1.24 & $0.80-1.93$ & 1077 & 1.38 & $0.92-2.06$ & 1040 & 1.97 & $1.50-2.60$ \\
\hline \multirow[t]{12}{*}{ Childhood Exposure } & Former smoking & & & & & & & & & \\
\hline & No & 870 & 1.18 & $0.71-1.95$ & 870 & 1.95 & $1.15-3.31$ & 840 & 1.06 & $0.78-1.45$ \\
\hline & Yes & 692 & 1.16 & $0.60-2.23$ & 692 & 1.57 & $0.85-2.92$ & 662 & 1.24 & $0.84-1.83$ \\
\hline & Obesity (BMI $\geq 30 \mathrm{~kg} / \mathrm{m}^{2}$ ) & & & & & & & & & \\
\hline & No & 1033 & 0.86 & $0.54-1.39$ & 1033 & 1.57 & $0.96-2.59$ & 995 & 0.92 & $0.69-1.23$ \\
\hline & Yes & 522 & 2.63 & $1.21-5.75$ & 522 & 2.63 & $1.31-5.29$ & 500 & 1.93 & $1.25-2.95$ \\
\hline & Currently in urban area & & & & & & & & & \\
\hline & No & 528 & 0.86 & $0.43-1.71$ & 528 & 1.15 & $0.60-2.19$ & 506 & 1.08 & $0.71-1.62$ \\
\hline & Yes & 1034 & 1.50 & $0.90-2.51$ & 1034 & 2.47 & $1.43-4.25$ & 996 & 1.24 & $0.92-1.68$ \\
\hline & Current SHS exposure & & & & & & & & & \\
\hline & No & 572 & 1.80 & $0.83-3.93$ & 572 & 2.71 & $1.18-6.20$ & 550 & 0.89 & $0.60-1.33$ \\
\hline & Yes & 990 & 1.04 & $0.65-1.66$ & 990 & 1.63 & $1.02-2.60$ & 952 & 1.29 & $0.95-1.75$ \\
\hline
\end{tabular}

a Logistic regression model adjusted for age, sex, race, job title, former smoking, pack-years, years since quitting, BMI, region of country, and urban residence except the stratification factor for each model, and also adjusted for either current exposure to SHS or childhood SHS exposure among never smokers or former smokers who quit at least 10 before completing the questionnaire.

* $\mathrm{p}$ for interaction $<0.05$.

associated with bronchitis symptoms (cough or phlegm) and asthmatic symptoms (wheeze, dyspnea, or chest tightness) [35]. Another study in 559 casino workers in London observed a significant relationship of intensity of workplace SHS exposure with shortness of breath and wheeze, controlling for home exposure [36]. Among workers in Spanish hospitality venues (bars, restaurants, hotels, and discotheques), respiratory symptoms decreased significantly [-98.1\% (95\% CI: $-51 \%$ to $-99.9 \%$ ) in multivariate analysis] after smoking was totally banned in their workplace, whereas there was no significant change among workers employed at hospitality venues where only partial smoking bans or no restrictions were implemented [37]. A study of Norwegian restaurant employees found a complete smoking ban in restaurants contributed to fewer reports of respiratory symptoms [38]. A small cross-sectional study in the former Yugoslav Republic of Macedonia found a significantly higher prevalence of wheezing and breathlessness in nonsmoking women who worked in offices with smokers as opposed to those who did not [39]. A study of Italian women found exposure at work resulted in higher adjusted odds of wheeze, shortness of breath and asthma symptoms [9]. A prospective telephone survey in Hong Kong focusing on workplace SHS exposure reported elevated risks of frequent cough and phlegm for those exposed at work compared to those unexposed [6]. Our study also found workplace SHS exposure to have the strongest effect on respiratory symptoms, as compared to home exposure or recreational exposure.

Workers in the trucking industry are exposed to occupational sources of airborne particles and gasses. Therefore, there is the potential for confounding by or synergism with other exposures on the association of SHS exposure with health outcomes. Previous evidence has shown that SHS exposure is independently associated with respiratory symptoms and decreased lung function after adjusting for other sources of 
Table 4 Effect modification of the association between lifetime home SHS exposure and respiratory symptoms ${ }^{\text {a }}$

\begin{tabular}{|c|c|c|c|c|c|c|c|c|c|c|}
\hline \multirow{2}{*}{$\begin{array}{l}\text { Stratification factors } \\
\text { Former smoking }\end{array}$} & \multirow{2}{*}{$\begin{array}{l}\text { Life-time home } \\
\text { exposure }\end{array}$} & \multicolumn{3}{|c|}{ Chronic cough } & \multicolumn{3}{|c|}{ Chronic phlegm } & \multicolumn{3}{|c|}{ Any wheeze } \\
\hline & & OR & $95 \% \mathrm{Cl}$ & $\mathrm{p}$ & OR & $95 \% \mathrm{Cl}$ & $\bar{p}$ & OR & $95 \% \mathrm{Cl}$ & $p$ \\
\hline \multirow[t]{4}{*}{ Yes } & Less than 10 years & ref & & & ref & & & ref & & \\
\hline & 10-19 years & 2.25 & $0.83-6.12$ & & 1.96 & $0.83-4.65$ & & 1.16 & $0.68-1.97$ & \\
\hline & 20-29 years & 2.47 & $0.94-6.48$ & & 2.09 & $0.91-4.78$ & & 1.18 & $0.71-1.96$ & \\
\hline & at least 30 years & 1.81 & $0.68-4.82$ & & 2.18 & $0.97-4.93$ & & 1.26 & $0.77-2.07$ & \\
\hline \multirow[t]{4}{*}{ No } & Less than 10 years & ref & & & ref & & & ref & & \\
\hline & 10-19 years & 1.04 & $0.56-1.91$ & & 1.79 & $0.99-3.24$ & & 1.21 & $0.84-1.74$ & \\
\hline & 20-29 years & 1.37 & $0.70-2.67$ & & 1.71 & $0.88-3.56$ & & 1.10 & $0.72-1.69$ & \\
\hline & at least 30 years & 1.17 & $0.58-2.35$ & & 1.54 & $0.77-3.10$ & & 1.33 & $0.86-1.69$ & \\
\hline \multicolumn{11}{|l|}{ Obesity (BMI $\geq 30$ kg/m²) } \\
\hline \multirow[t]{4}{*}{ Yes } & Less than 10 years & ref & & & ref & & & ref & & \\
\hline & 10-19 years & 3.42 & $1.18-9.90$ & & 2.45 & $1.07-5.59$ & & 1.55 & $0.91-2.63$ & \\
\hline & 20-29 years & 5.99 & $1.99-18.02$ & & 2.32 & $0.95-5.56$ & & 1.88 & $1.04-3.40$ & \\
\hline & at least 30 years & 4.78 & $1.61-14.23$ & & 2.84 & $1.21-6.70$ & & 2.27 & $1.28-4.03$ & \\
\hline \multirow[t]{4}{*}{ No } & Less than 10 years & ref & & & ref & & & ref & & \\
\hline & 10-19 years & 1.03 & $0.56-1.89$ & & 1.61 & $0.87-2.99$ & & 1.11 & $0.77-1.59$ & \\
\hline & 20-29 years & 1.12 & $0.60-2.10$ & & 1.78 & $0.96-3.33$ & & 1.00 & $0.68-1.46$ & \\
\hline & at least 30 years & 0.77 & $0.39-1.53$ & & 1.49 & $0.77-2.87$ & & 1.07 & $0.72-1.58$ & \\
\hline
\end{tabular}

Currently in urban area

\begin{tabular}{|c|c|c|c|c|c|c|c|}
\hline \multirow[t]{4}{*}{ Yes } & Less than 10 years & ref & & ref & & ref & \\
\hline & 10-19 years & 1.65 & $0.87-3.11$ & 2.25 & $1.19-4.22$ & 1.47 & $1.01-2.15$ \\
\hline & 20-29 years & 1.81 & $0.94-3.48$ & 2.31 & $1.21-4.42$ & 1.19 & $0.80-1.78$ \\
\hline & at least 30 years & 1.35 & $0.69-2.67$ & 1.94 & $1.01-3.75$ & 1.47 & $0.99-2.19$ \\
\hline \multirow[t]{4}{*}{ No } & Less than 10 years & ref & & ref & & ref & \\
\hline & 10-19 years & 0.88 & $0.35-2.22$ & 1.26 & $0.57-2.79$ & 0.90 & $0.55-1.49$ \\
\hline & 20-29 years & 1.78 & $0.72-4.42$ & 1.37 & $0.58-3.22$ & 1.16 & $0.67-2.01$ \\
\hline & at least 30 years & 1.47 & $0.58-3.73$ & 1.99 & $0.85-4.62$ & 1.13 & $0.64-1.98$ \\
\hline \multicolumn{8}{|c|}{ Current SHS exposure } \\
\hline \multirow[t]{4}{*}{ Yes } & Less than 10 years & ref & & ref & & ref & \\
\hline & 10-19 years & 1.39 & $0.77-2.52$ & 1.75 & $0.99-3.09$ & 1.43 & $0.97-2.11$ \\
\hline & 20-29 years & 1.13 & $0.60-2.14$ & 1.41 & $0.77-2.58$ & 1.39 & $0.92-2.10$ \\
\hline & at least 30 years & 1.02 & $0.55-1.89$ & 1.32 & $0.74-2.37$ & 1.19 & $0.81-1.76$ \\
\hline \multirow[t]{4}{*}{ No } & Less than 10 years & ref & & ref & & ref & \\
\hline & 10-19 years & 1.53 & $0.52-4.48$ & 2.86 & $1.00-8.16$ & 1.01 & $0.63-1.64$ \\
\hline & 20-29 years & 5.21 & $1.89-14.42$ & 3.94 & $1.37-11.33$ & 0.88 & $0.51-1.50$ \\
\hline & at least 30 years & 2.84 & $0.87-9.24$ & 5.38 & $1.69-17.15$ & 1.31 & $0.71-2.40$ \\
\hline
\end{tabular}

a Logistic regression model adjusted for age, sex, race, job title, former smoking, pack-years, years since quitting, BMI, region of country, and urban residence except the stratification factor for each model among never smokers or former smokers who quit at least 10 years before completing the questionnaire. * $p$ for interaction $<0.05$.

indoor particulate pollutants (e.g. wood stoves, candles, and gas cooking) in the general Danish population [5] and Singaporean women [40]. In this study we observed significant associations between SHS exposure and respiratory symptoms even with adjustment for job title, a fairly reasonable indicator of occupational exposure to air pollutants in this industry [25].
We recognize that this study has several limitations. It is a cross-sectional survey, limiting our ability to assess causality. The response rate, although comparable to other occupational studies [6,36], was only $64 \%$ of the people who received the second questionnaire. However, the responders and nonresponders were similar in terms 
of age, race, job title and active smoking. Both the exposures and the outcomes were self reported; therefore, the potential that recall bias could be responsible for our positive results cannot be ignored. In a study of workers in the same trucking companies we previously have shown evidence that self-reported workplace exposures to SHS are predictive of vapor-phase nicotine exposure as measured by a passive monitor worn on the lapel [22], providing evidence of validity of the self report of workplace exposure. It is unlikely that exposure only in the last 7 days would be causally related to chronic respiratory symptoms. However, it is likely that the recent exposure is reflective of more chronic exposures in the workplace, home and recreational facilities. Finally, there might be confounding by socioeconomic status and/or social stress. However, our study population is a group of blue-collar workers with fairly homogeneous backgrounds, and additional adjustment for educational level did not influence the results (data not shown). Thus, social factors are not likely to affect the results observed in this study.

\section{Conclusions}

In this population of non-smoking blue-collar workers, self-reported SHS exposure is associated with selfreported chronic cough, chronic phlegm, and any wheeze. The strongest associations were observed with exposures experienced in the workplace. After adjusting for current SHS exposure, childhood exposure is associated with chronic phlegm. This adds to the body of literature supporting the importance of ensuring smoke-free workplaces.

\section{Abbreviations}

SHS: Secondhand smoke; BMI: Body mass index.

\section{Competing interests}

The authors declare that they have no competing interests.

\section{Authors' contributions}

FL conceived of the study, designed the statistical analysis, interpreted the results and drafted the manuscript. Y-HC performed the statistical analysis and helped to draft the manuscript. EG and SKH participated in the design of the study and the interpretation of the results. JEH participated in the design and coordination of the study, the statistical analysis, interpretation of results, and drafting of the manuscript. All authors read and approved the final manuscript.

\section{Acknowledgments}

This study was supported by the Flight Attendants Medical Research Institute (FAMRI) Young Investigators Award and NIH/NCI R01 CA90792.

\section{Author details}

${ }^{1}$ Department of Environmental Health, Harvard School of Public Health, Boston, MA, USA. ²Department of Epidemiology, Harvard School of Public Health, Boston, MA, USA. ${ }^{3}$ Channing Division of Network Medicine, Department of Medicine, Brigham and Women's Hospital and Harvard Medical School, Boston, MA, USA. ${ }^{4}$ Pulmonary and Critical Care Medicine Section, Medical Service, VA Boston Healthcare System, Boston, MA, USA. ${ }^{5}$ Environmental Health Sciences Division, School of Public Health, University of California, Berkeley, CA, USA
Received: 15 October 2012 Accepted: 29 January 2013

Published: 1 February 2013

\section{References}

1. CDC: The health consequences of involuntary exposure to tobacco smoke: $A$ report of the Surgeon General. Atlanta, GA: Centers for Disease Control and Prevention; 2006.

2. Blanc PD, Ellbjar S, Janson C, Norback D, Norrman E, Plaschke P, Toren K: Asthma-related work disability in Sweden. The impact of workplace exposures. Am J Respir Crit Care Med 1999, 160:2028-2033.

3. Eisner MD, Wang Y, Haight TJ, Balmes J, Hammond SK, Tager IB: Secondhand smoke exposure, pulmonary function, and cardiovascular mortality. Ann Epidemiol 2007, 17:364-373.

4. Hammad M, Atta K, Manzoor M, Tariq M, Saeed Z, Masood Z, Saleem K, Raza M, Malik GM, Alam AY: Association of passive smoking with respiratory symptoms and clinical correlates, among married women, in a rural community in Islamabad. J Pak Med Assoc 2010, 60:601-604.

5. Hersoug LG, Husemoen LL, Sigsgaard T, Madsen F, Linneberg A: Indoor exposure to environmental cigarette smoke, but not other inhaled particulates associates with respiratory symptoms and diminished lung function in adults. Respirology 2010, 15:993-1000.

6. Ho SY, Lam TH, Chung SF, Lam TP: Cross-sectional and prospective associations between passive smoking and respiratory symptoms at the workplace. Ann Epidemiol 2007, 17:126-131.

7. Health Effects of Exposure to Environmental Tobacco Smoke: The Report of the California Environmental Protection Agency. Smoking and Tobacco Control Monograp: Health Effects of Exposure to Environmental Tobacco Smoke: The Report of the California Environmental Protection Agency. Smoking and Tobacco Control Monograph no. 10. Bethesda, MD: U.S: Department of Health and Human Services, National Institutes of Health, National Cancer Institute; 1999.

8. Reh DD, Lin SY, Clipp SL, Irani L, Alberg AJ, Navas-Acien A: Secondhand tobacco smoke exposure and chronic rhinosinusitis: a population-based case-control study. Am J Rhinol Allergy 2009, 23:562-567.

9. Simoni M, Baldacci S, Puntoni R, Pistelli F, Farchi S, Lo Presti E, Pistelli R, Corbo G, Agabiti N, Basso S, et al: Respiratory symptoms/diseases and environmental tobacco smoke (ETS) in never smoker Italian women. Respir Med 2007, 101:531-538.

10. Tammemagi CM, Davis RM, Benninger MS, Holm AL, Krajenta R: Secondhand smoke as a potential cause of chronic rhinosinusitis: a case-control study. Arch Otolaryngol Head Neck Surg 2010, 136:327-334

11. Voll-Aanerud M, Eagan TM, Wentzel-Larsen T, Gulsvik A, Bakke PS: Respiratory symptoms, COPD severity, and health related quality of life in a general population sample. Respir Med 2008, 102:399-406.

12. CDC: Reducing tobacco use: A report of the surgeon general. Atlanta, GA: Centers for Disease Control and Prevention; 2000.

13. CDC: Cigarette Smoking Among Adults - United States, 2004. MMWR Morb Mortal Wkly Rep 2005, 54:1121-1124.

14. CDC: Vital signs: nonsmokers' exposure to secondhand smoke - United States, 1999-2008. MMWR Morb Mortal Wkly Rep 2010, 59:1141-1146.

15. Alexander LA, Crawford T, Mendiondo MS: Occupational status, work-site cessation programs and policies and menthol smoking on quitting behaviors of US smokers. Addiction 2010, 105(Suppl 1):95-104.

16. Bang KM, Kim JH: Prevalence of cigarette smoking by occupation and industry in the United States. Am J Ind Med 2001, 40:233-239.

17. Gerlach KK, Shopland DR, Hartman AM, Gibson JT, Pechacek TF: Workplace smoking policies in the United States: results from a national survey of more than 100,000 workers. Tob Control 1997, 6:199-206.

18. Lee DJ, Fleming LE, Arheart KL, LeBlanc WG, Caban AJ, Chung-Bridges K, Christ SL, McCollister KE, Pitman T: Smoking rate trends in U.S. occupational groups: the 1987 to 2004 National Health Interview Survey. J Occup Environ Med 2007, 49:75-81.

19. Nelson DE, Emont SL, Brackbill RM, Cameron LL, Peddicord J, Fiore MC: Cigarette smoking prevalence by occupation in the United States. A comparison between 1978 to 1980 and 1987 to 1990. J Occup Med 1994, 36:516-525.

20. USHHS: Results from the 2008 National Survey on Drug Use and Health: National Findings. Cigarette use among adults employed full time, by occupational category. Publication no. SMA 09-4434, NSDUH Series H-36. US. Rockville MD: Department of Health and Human Services, Substance Abuse and Mental Health Services Administration, Office of Applied Studies; 2008. 
21. Wortley PM, Caraballo RS, Pederson LL, Pechacek TF: Exposure to secondhand smoke in the workplace: serum cotinine by occupation. J Occup Environ Med 2002, 44:503-509.

22. Chiu YH, Hart JE, Spiegelman D, Garshick E, Smith TJ, Dockery DW, Hammond SK, Laden F: Workplace secondhand smoke exposure in the U.S. trucking industry. Environ Health Perspect 2010, 118:216-221.

23. Jain NB, Hart JE, Smith TJ, Garshick E, Laden F: Smoking behavior in trucking industry workers. Am J Ind Med 2006, 49:1013-1020.

24. Ferris BG: Epidemiology Standardization Project (American Thoracic Society). Am Rev Respir Dis 1978, 118:1-120.

25. Smith TJ, Davis ME, Reaser P, Natkin J, Hart JE, Laden F, Heff A, Garshick E: Overview of particulate exposures in the US trucking industry. J Environ Monit 2006, 8:711-720.

26. David GL, Koh WP, Lee HP, Yu MC, London SJ: Childhood exposure to environmental tobacco smoke and chronic respiratory symptoms in non-smoking adults: the Singapore Chinese Health Study. Thorax 2005, 60:1052-1058

27. Hole DJ, Gillis CR, Chopra C, Hawthorne VM: Passive smoking and cardiorespiratory health in a general population in the west of Scotland. BMJ 1989, 299:423-427.

28. Janson C, Chinn S, Jarvis D, Zock JP, Toren K, Burney P: Effect of passive smoking on respiratory symptoms, bronchial responsiveness, lung function, and total serum IgE in the European Community Respiratory Health Survey: a cross-sectional study. Lancet 2001, 358:2103-2109.

29. Kauffmann F, Dockery DW, Speizer FE, Ferris BG Jr: Respiratory symptoms and lung function in relation to passive smoking: a comparative study of American and French women. Int J Epidemiol 1989, 18:334-344.

30. Larsson ML, Loit HM, Meren M, Polluste J, Magnusson A, Larsson K, Lundback B: Passive smoking and respiratory symptoms in the FinEsS Study. Eur Respir J 2003, 21:672-676.

31. Schwartz J, Zeger S: Passive smoking, air pollution, and acute respiratory symptoms in a diary study of student nurses. Am Rev Respir Dis 1990, 141:62-67.

32. Skorge TD, Eagan TM, Eide GE, Gulsvik A, Bakke PS: The adult incidence of asthma and respiratory symptoms by passive smoking in uterus or in childhood. Am J Respir Crit Care Med 2005, 172:61-66.

33. Svanes C, Omenaas E, Jarvis D, Chinn S, Gulsvik A, Burney P: Parental smoking in childhood and adult obstructive lung disease: results from the European Community Respiratory Health Survey. Thorax 2004, 59:295-302.

34. Gupta D, Aggarwal AN, Chaudhry K, Chhabra SK, D'Souza GA, Jindal SK, Katiyar SK, Kumar R, Shah B, Vijayan VK: Household environmental tobacco smoke exposure, respiratory symptoms and asthma in non-smoker adults: a multicentric population study from India. Indian J Chest Dis Allied Sci 2006, 48:31-36.

35. Jayet PY, Schindler C, Schwartz J, Kunzli N, Zellweger JP, AckermannLiebrich U, Leuenberger P: Passive smoking exposure among adults and the dynamics of respiratory symptoms in a prospective multicenter cohort study. Scand I Work Environ Health 2005, 31:465-473.

36. Pilkington PA, Gray S, Gilmore AB: Health impacts of exposure to second hand smoke (SHS) amongst a highly exposed workforce: survey of London casino workers. BMC Publ Health 2007, 7:257.

37. Fernandez E, Fu M, Pascual JA, Lopez MJ, Perez-Rios M, Schiaffino A, Martinez-Sanchez JM, Ariza C, Salto E, Nebot M: Impact of the Spanish smoking law on exposure to second-hand smoke and respiratory health in hospitality workers: a cohort study. PLoS One 2009, 4:e4244.

38. Skogstad M, Kjaerheim K, Fladseth G, Molander P: Smoking ban in restaurants and respiratory symptoms among employees. Tidsskr Nor Laegeforen 2011, 131:2119-2121.

39. Minov J, Karadzinska-Bislimovska J, Vasilevska K, Risteska-Kuc S, Stoleski S: Effects of passive smoking at work on respiratory symptoms, lung function, and bronchial responsiveness in never-smoking office cleaning women. Arh Hig Rada Toksikol 2009, 60:327-334.

40. Ng TP, Hui KP, Tan WC: Respiratory symptoms and lung function effects of domestic exposure to tobacco smoke and cooking by gas in non-smoking women in Singapore. J Epidemiol Community Health 1993, 47:454-458.

\section{doi:10.1186/1471-2458-13-93}

Cite this article as: Laden et al: A cross-sectional study of secondhand smoke exposure and respiratory symptoms in non-current smokers in the U.S. trucking industry: SHS exposure and respiratory symptoms. BMC Public Health 2013 13:93.

\section{Submit your next manuscript to BioMed Central and take full advantage of:}

- Convenient online submission

- Thorough peer review

- No space constraints or color figure charges

- Immediate publication on acceptance

- Inclusion in PubMed, CAS, Scopus and Google Scholar

- Research which is freely available for redistribution 